\title{
Chemical hazards in construction industry
}

\author{
Tomasz Kowalik, Dominik Logoń, Marek Maj, Jarosław Rybak ${ }^{*}$, Aleksandra Ubysz and \\ Anna Wojtowicz
}

Wroclaw University of Science and Technology, Wybrzeże Wyspiańskiego 27, 50370 Wrocław

\begin{abstract}
Rapid technological progress in construction requires that more and more attention should be paid to human security issues. Threats occur both at the stage of building facilities and during their use. Some impacts are easy to identify during construction stage like shocks and vibrations, others are hidden from sight and direct sensing like the harmful effect of chemicals. In addition to accidents that happen on construction sites, there are still objective threats, which may occur throughout the lifetime of the facility. In addition to clearly perceptible ones such as earthquakes, hurricanes, fires, there are hidden threats as well: bacteriological contamination, radiation or chemical interactions that occur in time. This article points to the most common chemical hazards. Examples of chemical threats occurring in construction at the stages of design, construction and use of buildings will be given below.
\end{abstract}

\section{Introduction}

Nowadays, many diseases result from the progress of civilization. People, due to their activities are exposed to various unexpected impacts. Solutions that make our daily life easier are not always safe for health. Examples include various sources of vibrations, radiation from mobile phones, car exhausts or food preservatives. Such dangers are also observed in the construction industry [1]. Standards and building codes have required safety certificates for many years now [2-5]. Detailed regulations specify safe levels of various contaminations with substances and impacts that threaten health. Rapid technological progress in the field of building materials means that not all health-threatening factors are recognized. Moreover, tests required to certify products for use are also carried out according to specific procedures. The criteria for these procedures are most often associated with the purpose of the product. In practice, unfortunately, some products are not stored or used in accordance with the manufacturer's intention (too high or too low temperature, permissible humidity range exceeded, improper transport, contact with materials that trigger chemical reactions, etc.). In these cases, there is a great danger that such products will pose a real threat to those who use them, as well as those who will be users of facilities built according to technologies that do not comply with the Manufacturer's requirements.

\footnotetext{
${ }^{*}$ Corresponding author: jaroslaw.rybak@pwr.edu.pl
} 
Identification and spreading of knowledge about potential threats should be a part of new sustainable ways of developing building industry. Some examples concerning the construction works were already given for construction induced vibrations in work [6].

\section{Construction raw materials}

There are two main sources of potential chemical risk directly from the materials used at the building site. First group is used for the production of composites - these are harmful mineral binders, mainly based on Portland cement with additives. The second group consist of ready construction materials produced from potentially harmful substrates.

\subsection{Mineral binders}

Portland cement clinker contains a product that is a threat to both people and the environment. Clinker and dust from the production of Portland cement are a strongly alkaline environment after reaction with water. The basic components of the clinker are:

- tricalcium silicate (50-65\% of clinker mass) $-3 \mathrm{CaO} \cdot \mathrm{SiO}_{2}$ (alit)

- dicalcium silicate (about $20 \%$ of clinker mass) $-2 \mathrm{CaO} \cdot \mathrm{SiO}_{2}$ (belit)

- $\mathrm{Ca}_{3} \mathrm{Al}_{2} \mathrm{O}_{6}\left(3 \mathrm{CaO} \cdot \mathrm{Al}_{2} \mathrm{O}_{3}-\mathrm{C}_{3} \mathrm{~A}\right)$ reacts with water the fastest (celite)

- compound of calcium, aluminium and iron oxides $-4 \mathrm{CaO} \cdot \mathrm{Al}_{2} \mathrm{O}_{3} \cdot \mathrm{Fe}_{2} \mathrm{O}_{3}$ (brownmilleryt)

- tricalcium aluminate $-3 \mathrm{CaO} \cdot \mathrm{Al}_{2} \mathrm{O}_{3}$

Each of these compounds undergoes hydration in contact with water:

- $3 \mathrm{CaO} \cdot \mathrm{Al}_{2} \mathrm{O}_{3}+6 \mathrm{H}_{2} \mathrm{O} \Rightarrow 3 \mathrm{CaO} \cdot \mathrm{Al}_{2} \mathrm{O}_{3} \cdot 6 \mathrm{H}_{2} \mathrm{O}$

- $2 \mathrm{CaO} \cdot \mathrm{SiO}_{2}+\mathrm{H}_{2} \mathrm{O} \Rightarrow 2 \mathrm{CaO} \cdot \mathrm{SiO}_{2} \cdot \mathrm{H}_{2} \mathrm{O}$

- $3 \mathrm{CaO} \cdot \mathrm{SiO}_{2}+2 \mathrm{H}_{2} \mathrm{O} \Rightarrow 2 \mathrm{CaO} \cdot \mathrm{SiO}_{2} \cdot \mathrm{H}_{2} \mathrm{O}+\mathrm{Ca}(\mathrm{OH})_{2}$

The product obtained is strongly alkaline $(12-13 \mathrm{pH})$. For humans, the greatest risk is the contact of these compounds with the humid environment: eyes, respiratory tract, moist skin. This impact is defined in terms of health risk as STOT SE (specific target organ toxicity - single exposure). This means there is a risk of serious eye damage or severe irritation of the respiratory tract or skin. In some cases, allergic reactions may occur due to the content of $\mathrm{Cr}$ chromium. This risk increases with a longer period of cement storage, since then the efficiency of the chromium reducer decreases.

\subsection{Construction materials}

Building elements that are made of concrete and similar materials can be a source of radiation. Natural radiation is in small amounts a natural environment for humans and does not threaten its health. It happens, however, that some materials show a higher level of radiation, which is not indifferent to health.

The phenomenon of radioactivity is also observed in ceramic hollow blocks, and sometimes at a higher level than in the case of concrete blocks. All materials used to build a house should therefore be controlled for radioactivity. In addition, you should pay attention to indirect impacts. The chemical environment may be the basis for other factors harmful to health. An example can be bacteriological and mycological contamination.

Wood-based materials can be included in materials that can be harmful. For their production, formaldehyde is used, which is dangerous both at the production stage and in the use of rooms. Formaldehyde is released into the atmosphere as a gas that can cause disease in high concentrations. People exposed to this gas emission may experience chest pain, weakness, watery eyes, as well as sensitization and irritation. Research confirms that formaldehyde can cause cancer in humans. 


\section{Harmful ingredients of paints}

The term "harmful substance" according to the Dictionary of terms used in toxicology of 1994 reads: "... it is a chemical agent that in contact with the human body can cause specific biological or health effects occurring during exposure or later, and also in the next generations." Paints are substances that form protective or decorative coatings on the surface of objects. They are usually in liquid form. They consist of many components, of which one can distinguish: binders (resins), thinners, pigments. Each of these elements has a different role in coating formation.

\subsection{Resins}

Resins, i.e. binders are found in all types of paints, varnishes and emulsions. They are responsible for the formation of a film on the surface of an object and give the paint properties such as gloss, strength, flexibility, adhesion, resistance to weather conditions. Binders may be synthetic or natural, e.g. polyurethanes, epoxy resins, vinyl acetate, silanes [7].

Polyurethane paints perfectly protect objects against corrosion and mechanical damage, therefore they have been used in the metallurgical and shipbuilding industries, but they also work well on substrates such as plaster, concrete, wood and plastics [8,9].

Chemically highly reactive isocyanates are the basic raw material for the synthesis of polyurethanes [10]. The most dangerous are their pairs, which get into the body through the respiratory system. They are also partially absorbed through the skin. Prolonged exposure to isocyanates causes occupational asthma.

Epoxy resin belongs to synthetic resins. It is an important component of paints and varnishes, adhesives or putty. They are resistant to high temperature, high load, strong chemical substances, and widely used in industry. Epoxy resin irritates eyes and skin, and can cause burns. Upon contact with the respiratory system, it causes its damage.

Vinyl paints are durable and cover well. They can be used on various substrates: plasters, drywall, wood. Their base is polyvinyl acetate, which has an irritating effect on mucous membranes; it causes eye tearing as well as smell disorders. After it has been absorbed into the body, usually through the respiratory tract but also through the digestive system, it causes dizziness, drowsiness, coughing. Polyvinyl acetate causes dysfunction of the central nervous system. In an experimental study of human exposure to low levels of vinyl acetate, functional abnormalities in the electroencephalographic record were found.

\subsection{Solvents}

Solvents are liquids that dissolve film-forming substances that form a binder of paints and varnishes [11]. Most often they are: gasoline, benzene, turpentine, ethyl alcohol. They exhibit high volatility and thus can create high concentrations in the air. Benzene is highly toxic. It causes damage to the nervous system. It is absorbed mainly from the respiratory tract, rarely through the skin and from the gastrointestinal tract. It is considered to be carcinogenic; it damages the bone marrow. People who are professionally exposed to benzene have an increased incidence of leukaemia.

Solvents cause permanent damage to your hearing. The first studies on this subject come from the early 1980s. They affect the peripheral and central part of the auditory pathway and the balance system. Prolonged exposure to organic solvents causes chronic toxic encephalopathy, which is recognized as an occupational disease. This disease leads to diffuse changes in the brain. 


\subsection{Pigments}

The main task of pigments is to protect the organic resin against UV radiation and corrosion. Not all pigments are toxic, but some of them contain heavy metals such as cadmium or lead.

Cadmium naturally occurs in zinc and lead ores, and has highly toxic properties. It protects against corrosion very well, which is why it is widely used in industry.

Cadmium poisoning occurs mainly in metallurgy. The body accumulates the element in the internal organs (liver, kidneys, pancreas), thus damaging them. It causes serious foetal defects and is therefore particularly dangerous for pregnant women.

All lead compounds are poisonous. It penetrates the body through the digestive and respiratory system causing lead poisoning, which is a chronic poisoning with lead and its salts. Lead accumulates in the brain, kidneys and liver, damaging these organs. Among the chronic effects of lead, lead neuropathy is mentioned (dementia, hallucinations, muscle tremors, concentration and memory disorders), as well as atherosclerosis and cardiac infarction resulting from it.

\section{Measures for protection against chemical substances}

\subsection{Personal protection measures}

Personal protective equipment against hazards from chemical substances are: protective clothing, face and eye protection, respiratory protection. They should be used in situations where threats cannot be avoided or sufficiently mitigated by means of collective protection or appropriate organization of work $[12,13]$. Thanks to them, you can reduce the likelihood of an accident and minimize its health effects [14].

a) Clothing protecting against chemical agents directly protects against very serious threats, often even fatal ones. It is divided into 6 basic types:

- Type 1 and Type 2 Clothing protecting against chemical substances in the form of gases, vapours, liquids and fine solid particles

- Type 3 Protective clothing against the action of a liquid stream

- Type 4 Protective clothing against the action of sprayed liquid

- Type 5 Clothing protecting against dust

- Type 6 Clothing with limited protection against liquid chemicals

b) Eye and face protection prevents among others eye damage due to mechanical, chemical, thermal and other factors. Eye protection equipment:

- safety glasses,

- protective goggles,

- face shields,

- welding shields

- goggles (better adherence to the face than glasses) and face shields that prevent direct contact with the skin and eyes are most commonly used to protect against chemicals. As a result, irritation and more severe burns are avoided.

c) Respiratory protection is of particular importance. Substances absorbed into the body this way cause many dangerous diseases, also life-threatening diseases. There are two basic protection methods:

- cleaning the inhaled air

- supplying air from sources free of impurities 
Cleaning equipment purifies the inhaled air from harmful chemicals and dust. Cleaning equipment includes: filters to stop dusts and mists, absorbers to stop gases on the principle of chemical reaction and filter-absorbers, which are a combination of filters and absorbers. Insulating equipment ensures supply of clean air, so that toxic substances do not reach the lungs and then other parts of a worker's body.

\subsection{Safe storage of chemical substances}

People who have contact with chemical substances should be trained in terms of their storage, the risks involved and preventing them. Chemical substances ought to be stored in such a way that they do not pose any hazard.

Poisoning, explosions and fires are the basic risks linked to storing chemicals. Ventilation and signalling devices should be provided in a facility with dangerous reagents [15]. The height of storage at work without lifts should not exceed $1.5 \mathrm{~m}$. Hazardous substances in glass packaging should be stored on the lowest shelves. Access to extinguishing and neutralizing agents should be ensured; agents and measures must be adapted to the type of danger. Flammable substances, if their storage is truly required, should be stored in the smallest possible quantities; all precautions recommended by the manufacturer must be observed.

Substances that may interact with each other should be stored away from each other. Containers must be properly marked, set in designated places. Vessels and equipment in contact with a toxic substance should be marked in a permanent and visible manner.

\section{Conclusions}

The constant progress in material sciences and increasing use of new construction materials and technologies has resulted in new risks for building site employees and final users of construction facilities. New technologies introduce more and more complex composite materials which could not be tested in a long time period before implementing. Composites using waste or recycled materials are already an increasingly important element of buildings [16-17]. Also the energy sector promotes the use of fly ashes (spoil material of coal burning) in building industry as a substitute of cementous binders. However, in terms of $\mathrm{CO}_{2}$ production fly ashes are "zero emitting materials", other threats related to radiation should be considered. In this and other cases, there is still a problem with secondary chemical threats from composite materials. Attention should be paid not only to short-term and long-term impact the direct threat to people with, but also to indirect hazards, which are harmful to the environment. The presented topic only shows examples of threats that must be examined and published in the form of building standards and regulations.

This paper has been written as part of the research project: "Industrialized construction process (Construction 4.0). Technological and methodological conditions of application of selected composite elements in civil engineering". The project is being carried out jointly with Peoples' Friendship University of Russia in Moscow. Research project PWr-RUDN 2017 no. 45WB / 0001/17 Industrialized Construction Process.

\section{References}

1. Ubysz, M. Maj, M. Musiał, J. Ubysz, Radon - occurrence and health risks in civil engineering. Procedia Engineering, 172, 1184-1189, (2017) 
2. H. Puchalska, Czynniki wpływające na toksyczność substancji chemicznych [Factors impacting toxicity of chemical substances], Bezpieczeństwo Pracy: nauka i praktyka, 4, 12-14, (1999)

3. A. Markom, N. Hjorth, Occupational health and safety in small and mediumsized enterprises in the chemical industry, manufacture of rubber and plastic products, Publication prepared as part of the project financed by the European Union PL2002/000-196.01.0; Project contractor: Österreichische Akademie für Arbeitsmedizin, ISBN 3-86611-029-4, (2005)

4. Z. Florjańczyk, S. Penczek, Chemia polimerów Tom II, Oficyna Wydawnicza Politechniki Warszawskiej, ISBN 83-7207-368-6, (2002)

5. W. Domański, Bezpieczeństwo pracy przy magazynowaniu chemikaliów [Occupational safety in chemical storage], Bezpieczeństwo Pracy. Nauka i Praktyka, 4 (499), 19-21, (2013)

6. O. Lohunova, M. Wyjadłowski, Modification of vibratory driving technology for sustainable construction works, MATEC Web of Conf., 151, 03063, (2018)

7. P. Czub, Z. Bończa-Tomaszewski, P. Pęczek, J. Pielichowski, Chemia i technologia żywic epoksydowych [Chemistry and technology of epoxy resins], WNT, Warszawa, ISBN 83-2042-611-1, (2002)

8. R.T. Morrison, R.N. Boyd; Chemia Organiczna [Organic chemistry]; Wydawnictwo Naukowe PWN, Warszawa, 260, ISBN 83-01-04166-8, (1997)

9. J. Banera, M. Maj, A. Ubysz, Powłoki polimocznikowe w budownictwie : kompendium wiedzy projektanta, wykonawcy, inwestora i użytkownika. Poznań, DTP : D-Concept, Grupa MD, 336, (2017)

10. S. Brzeźnicki, M. Bonczarowska; Zawodowe narażenie na wybrane izocyjany w polskim przemyśle [Occupational exposure to selected isocyanates in Polish industry]; Medycyna Pracy, 66 (3), 291-301, (2015)

11. E. Zamysłowska-Szmytke, M. Śliwińska-Kowalska, Działanie wybranych rozpuszczalników organicznych na narząd słuchu i układ równowagi [The influence of organic solvents on hearing and balance]; Medycyna Pracy, 64 (1), 83-102, (2013)

12. I. Krzywy, E. Krzywy, M. Pastuszak-Gabinowska, A. Brodkiewicz; Ołów - czy jest się czego obawiać? [Lead - Is there something to fear?], Annales Academiae Medicae Stetinensis - Rocznik Pomorskiej Akademii Medycznej w Szczecinie, 56 (2), 118-128, (2010)

13. M. Śliwińska-Kowalska, Audiologia kliniczna. [Clinical audiology]; Mediton, Łódź, ISBN: 83-913433-8-3, (2005)

14. I. Krzywy, E. Krzywy, J. Peregud-Pogorzelski, K. Łuksza, A. Brodkiewicz; Kadm - Czy jest się czego obawiać? [Cadmium - Is there something to fear?]; Annales Academiae Medicae Stetinensis- Rocznik Pomorskiej Akademii Medycznej w Szczecinie, 57 (3), 49-63, (2011)

15. E. Gawęda, H. Puchalska; Rozporządzenie REACH - wymagania dotyczące karty charakterystyki substancji chemicznej [REACH - requirements concerning Safety Data Sheets for chemical substances]; Bezpieczeństwo pracy- nauka i praktyka, 10, 8-12, (2008)

16. J. Kawalec, S. Kwiecień, A. Pilipenko, J. Rybak, Application of crushed concrete in geotechnical engineering - selected issues, IOP Conf. Series: Earth and Environmental Science, 95, 022057, (2017)

17. A. Pilipenko, S. Bazhenova, Usage of crushed concrete fines in decorative concrete, IOP Conf. Series: Materials Science and Eng., 245 (2), 032082, (2017) 